\title{
CONVERSAÇÕES ENTRE ARTES \& CULTURAS A PARTIR DE OLHARES ANTROPOLÓGICOS
}

\author{
John Fletcher $^{1}$ \\ Agenor Sarraf ${ }^{2}$ \\ Ernani Chaves $^{3}$
}

\section{Considerações Iniciais}

A esfera que compõe as artes não se diferencia em complexidade dos seus referentes sociais. Também caracterizadas, em suas formulações polifônicas ${ }^{4}$, descontínuas e assimétricas, por linguagens, estruturas, sistemas, atos, símbolos, padrões de sentimento (Geertz, 2008a), as artes servem de rastros/resíduos de indivíduos que optaram por enunciados visuais para desvendar mundos (Glissant, 2005; Campos et al, 2012).

Neste juízo dos processos artísticos nos seus respectivos contextos de significação - sistemas de pensamentos os quais podem ser expressos por formulações visuais (Lagrou, 2003) -, detectamos como as ciências sociais continuamente se empenham em traçar relações geohistóricas e socioculturais entre realidades, afetividades, temporalidades, paisagens e conflitos. De certa forma, pelo caso da antropologia, dentre as várias lentes voltadas para as concepções plásticas de narrativas, nos é possível ter uma parte inequívoca do saber interessado por buscar um lugar para as artes no contexto das demais criações humanas que essas expressões, em seu conjunto, dão sustentação (Geertz, 2008a).

Este artigo, ao defender que não existem sistemas de arte ou manifestações artísticas construídas fora dos modos de vida das sociedades, procura transitar pelas clássicas reflexões da antropologia em torno das noções convergentes de cultura e de arte. Ele ilustra como o pensamento não é invariável e precisa ser tratado, conforme detectou Geertz (2008b), na forma de um projeto de descrição analítica e reflexão interpretativa, capaz de tornar uma rede de entendimentos sociais em fragmentos os quais ora se reforçam mutuamente, ora modificam nossos olhares sobre o futuro.

\footnotetext{
${ }^{1}$ Universidade Federal do Pará, Brasil.

${ }^{2}$ Universidade Federal do Pará, Brasil.

${ }^{3}$ Universidade Federal do Pará, Brasil.

${ }^{4}$ A polifonia, um conceito estabelecido por Mikhail Bakhtin (2003), reconhece o diálogo e a criação artística como o encontro de diversas vozes, realidades e temporalidades, interceptando-se num ir e vir sem categorização.
} 
A base teórica que sustenta nossa interpretação das interfecundações (Viveiros de Castro; Goldman, 2012) e distanciamentos entre arte e antropologia, antropologia e arte, estabelece diálogos com o Culturalismo Boasiano, as Escolas Francesa de Sociologia, Estrutural Funcionalista, de Cultura e Personalidade e Estruturalista Lévi-Straussiana, alcançando o Interpretativismo de Clifford Geertz. Essas formas epistemológicas de compreender as artes, mesmo com suas distintas óticas de abordagem, servem de suportes para uma problemática complexa, transdisciplinar e, geralmente, inesperada, qual seja: discutir o lugar das artes na compreensão do pensamento social contemporâneo.

As críticas do pensamento social moderno sobre a ausência de cientificidade na constituição das artes revelam um alvo interpretativo e científico dualista que fraturou dimensões da experiência humana. A separação realizada pelo cientificismo entre arte e perspectiva social apontou limites da compreensão de sua própria constituição, pois toda forma de fazer ciência é contaminada por criação, montagem, ficção e razão. A assertiva filia-nos a Hissa (2013), quando percebe que a experimentação do mundo precede a razão - constatação a qual concebe a sinergia entre arte e ciência, dois tipos de enunciados os quais se entrecortam na base do estímulo e da reconstrução, simultaneamente.

\section{O Início das Diferenças e o Relativismo Cultural}

As ciências sociais modernas ganharam forma, aproximadamente, por volta de meados do século XIX na Europa e nos Estados Unidos. Estas esboçaram, desde seus primeiros questionamentos, uma atenção à questão sociocultural. Divididas em duas grandes vertentes, uma mPágina | 12onogenista e outra poligenista ${ }^{5}$, as comunidades científicas sociais desta época enfrentaram o desafio de pensar, à luz dos novos tempos, a origem dos indivíduos e suas relações históricas (Schwarcz, 1993), porém sem problematizar, em suas primeiras incursões, a diversidade de significações artísticas das sociedades.

\footnotetext{
${ }^{5}$ A vertente monogenista, formada por análises etnológicas e totalmente tributárias das escrituras bíblicas, aglutinava pensadores os quais descreviam que a humanidade era única, ao passo que a poligenista, também entendida como um ramo das ciências naturais, em virtude da crescente sofisticação das ciências biológicas e da contestação aos dogmas católicos, ressaltava a existência de vários centros de criação, correspondentes às diferenças raciais estabelecidas (Stocking, 1968; Schwarcz, 1993).
} 
As incursões primeiras dos estudos sociais, preocupadas com povos ditos "selvagens", muito em virtude das concepções e posturas detratoras elaboradas já no século anterior a partir do maior conhecimento e colonização de territórios conquistados, tiveram uma propagação acondicionada por ideias de evolução geral e unilinear da cultura, da qual participariam todos os indivíduos humanos (Schwarcz, 1993). Ironicamente, por esse argumento de melhor entender as origens da sociedade ocidental, continuaram como veículos de ruídos simplificadores e ficcionalizantes das cosmologias e dos juízos de povos não ligados aos eixos colonizadores (Said, 2007; Hofbauer, 2009).

Apreendidos por um universalismo progressista e construído para pensar a condição do outro em suas relações comunitárias, esses olhares sociais apregoavam uma noção de desenvolvimento destituída de um reconhecimento artístico que não fizesse parte dos cânones da história da arte "oficial” e basicamente definiam o começo cultural na barbárie, até um estado de civilização promovido por lentas acumulações de conhecimento experimental, de ações uniformes com causas uniformes (Morgan, 2005; Tylor, 2005). E, de fato, aos Darwinistas Sociais e Evolucionistas Sociais, apoiados em uma confiança de uma elite dominante, a qual depunha um estado do ser avassalador e subestimador, parecia fácil "fundar uma doutrina que classifica[va] sem nenhuma cerimônia as sociedades em 'mais avançadas' e 'menos avançadas', em 'bárbaras' e 'selvagens' e os costumes em 'promíscuos' e 'civilizados' ” (Da Matta, 1983: 09), a ponto de fortalecer, assim, novas problemáticas psico-históricas nas relações entre sociedades.

Essas abordagens historicamente localizadas, por vezes atreladas à crença iluminista de sociedades como sistemas naturais - organismos reduzíveis a princípios gerais - e amparadas por uma ânsia de conquista que resultou num modelo europeu neocolonialista (Evans-Pritchard, 1978; Da Matta, 1983) foram, então, alvo de inúmeras críticas. Algumas delas, em detrimento do método comparativo de elementos semelhantes em diferentes lugares e épocas do mundo, pois preconizavam outro mais específico para o estudo de culturas e de regiões culturais delimitadas (Da Matta, 1983; Castro, 2010), informavam que tais elementos, ainda que semelhantes, não poderiam ser rudemente aproximados, por revelarem percursos culturais impossíveis de ser comparados.

Iluminuras, Porto Alegre, v. 15, n. 35, p. 11-43, jan./jul. 2014 
Como observou o antropólogo Franz Boas, um dos mais proeminentes nomes para a quebra dos paradigmas Darwinista e Evolucionista Social,

\begin{abstract}
O fato de que muitos aspectos fundamentais da cultura sejam universais - ou que pelo menos ocorram em muitos lugares isolados - quando interpretados segundo a suposição de que os mesmos aspectos devem ter se desenvolvido sempre a partir das mesmas causas, leva à conclusão de que existe um grande sistema pelo qual a humanidade se desenvolveu em todos os lugares, e que todas as variações observadas não passam de detalhes menores dessa grande evolução uniforme. (...) $\mathrm{O}$ método histórico atingiu uma base mais sólida ao abandonar o princípio enganoso de supor conexões onde quer que se encontrem similaridades culturais. O método comparativo, não obstante tudo o que se vem escrevendo e dizendo em seu louvor, tem sido notavelmente estéril com relação a resultados definitivos (Boas, 2010: 32$38)$.
\end{abstract}

Impulsionado pelas fragilidades dos pensamentos socioevolucionistas, onde agora tudo se tornava individualidade, Boas (2010), assim como outros pesquisadores auxiliados por linhas de pesquisa insurgentes, buscou firmar, prática e teoricamente, uma relação de particularidades entre culturas, povos em seus ambientes, os quais eram capazes de revelar um processo de diferenciações, mesmo em esferas, até então, consideradas aparentes (Stocking Jr., 2004).

No caso desta linha de pensamento Culturalista, detentora de um dos primeiros modelos a adotar uma postura mais relativista para o caso da interpretação das sociedades, problematizou-se "o estudo de mudanças culturais aferidas através da análise de processos de transformações, a serem acompanhados muitas vezes passo a passo pela via da construção histórica e pela observação comparada" (Cardoso de Oliveira, 1988: 63). Por não mais optar pelo reconhecimento de etapas evolutivas, de forma que não haveria mais coerência em aproximar e generalizar aspectos que fossem semelhantes somente em sua aparência, uma vez que em sua própria metafísica poderiam se encontrar heterogeneidades - característica fundamental para mostrar a simplificação e impertinência de uma estratégia sob o foco do método comparativo proposto pelos socioevolucionistas (Da Matta, 1983; Boas, 2010b) -, o pensamento boasiano e culturalista pôde igualmente ser lido como um dos primeiros reflexos do encolhimento proporcionado pelas iniciais crises do império britânico, grande centro do pensamento evolucionista de culturas (Cardoso de Oliveira, 1988; 2003).

Foi nesse contexto de contra-argumentações que Boas (1955) pôde tecer, alguns anos mais tarde, as primeiras pesquisas sobre o mundo das artes para o campo da antropologia. Em Primitive Art, sua articulação mais complexa para envolver as artes 
em princípios teóricos advindos de suas críticas a um "evolucionismo reducionista ou um difusionismo que negava a criatividade à maior parte das culturas" (Lagrou, 2003: 107), a prática visual poderia ser encarada não somente por representações de valores estéticos distintos a denotar uma comprovação fundamental da cognição de todas as populações (uma unidade fundamental), porém também por fornecer resultados atrelados a histórias e psicologias culturais irrepetíveis e complexas (uma unidade cultural relativista, vide Figura 01) (Boas, 1955).
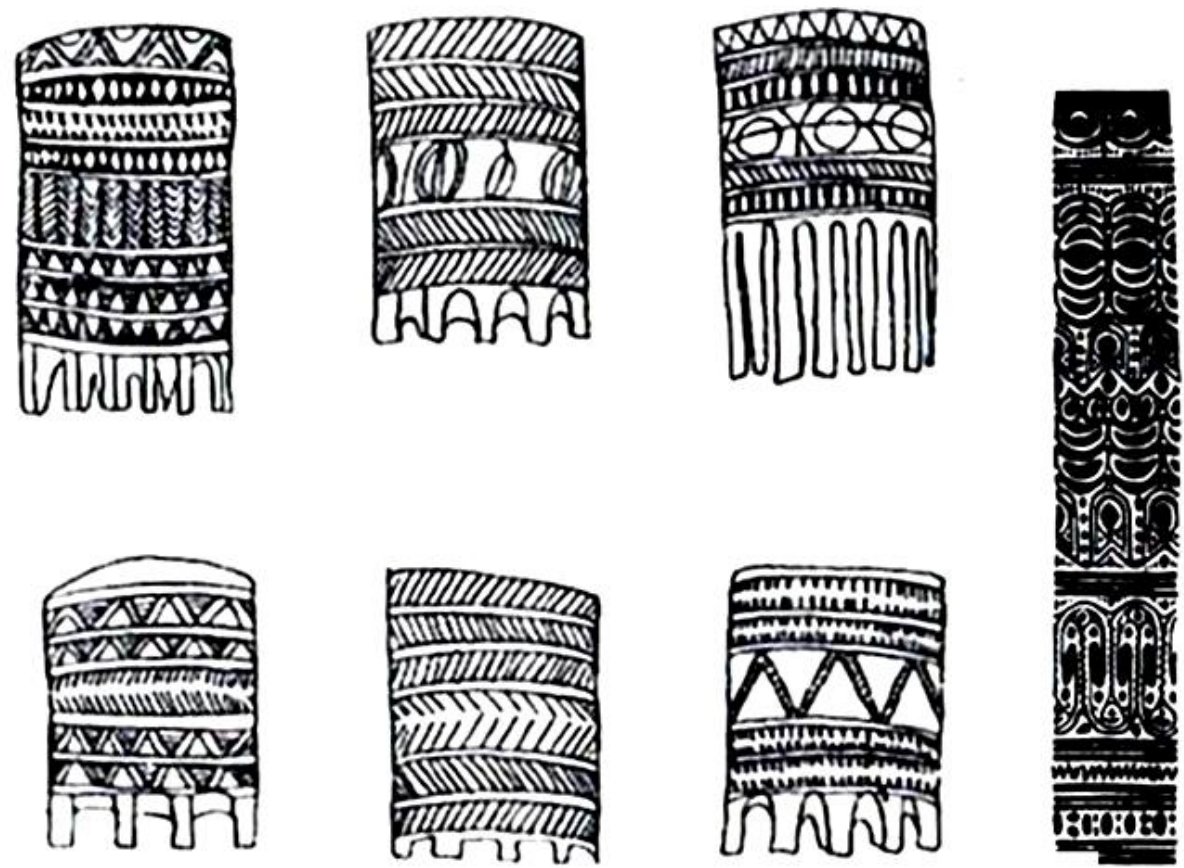

A

$\mathbf{B}$
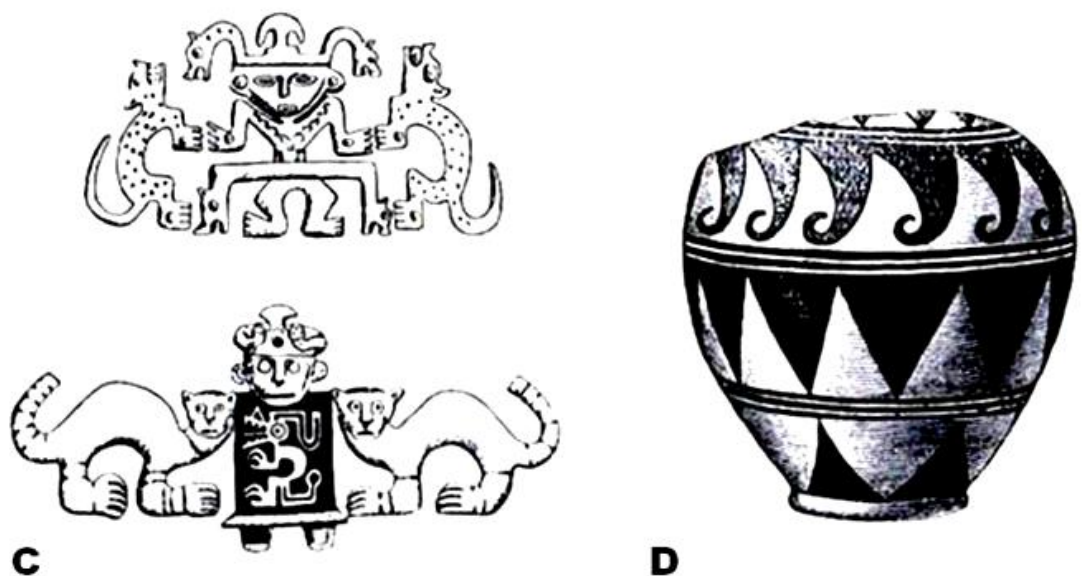

D 
Figura 01. Alguns desenhos de peças de grande valor artístico apresentadas por Franz Boas em Primitive Art. A - Padronagens em pentes de bambu, Península Malaia; B - Artefatos Peruanos; C - Padronagem de lança de bambu, Nova Guiné; D - Vaso etrusco. Fonte: Boas, 1955: 35.

As artes estudadas por Boas, eminentemente em sentido descritivo e adeptas do nominalismo "primitivas", longe de configurar um objeto teórico bem definido, constituíram uma das primeiras fases para se demarcar a "busca de regularidade e generalidade em fenômenos portadores de unidade objetiva e a tentativa de compreender a singularidade de fenômenos portadores de unidade apenas subjetiva" (Almeida, 1998: 08). Atentado que seus estudos estavam direcionados às produções visuais de povos externos aos eixos europeus e urbanos da América, Boas apreendeu que as artes indicavam suas indissociabilidades das culturas, por ser, ao mesmo tempo, faculdade primordial dos humanos e zona de impossibilidade para a existência de valores estáveis.

\begin{abstract}
It remains to be seen whether it is possible to derive generally valid laws that control the growth of specific art styles (...). With increasing technical skill and perfection of tolls, changes are bound to occur. Their course is determined by the general cultural history of the people. We are not in a position to say that the same tendencies, modified by local historical happenings, reappear in the course of art development everywhere (Boas, 1955: 07). ${ }^{6}$
\end{abstract}

Ao levar em consideração que houve tempos nos quais as condições técnicas e lógicas do homem eram diferentes, e não inferiores ou superiores, suas características poderiam remontar a práticas mais ancestrais - período que se estende para os desertos do passado, sem deixar resquícios etnográficos mais completos -, Boas endossou como todas as fontes existentes poderiam auxiliar em investigações e desdobraduras sociais. Essas fontes, mesmo relacionadas a determinados tipos formais, inevitavelmente trariam uma íntima relação com os olhares fruidores de suas respectivas comunidades, em virtude de seus apelos estéticos partilhados e adotados.

James Clifford (1988), um dos teóricos que já na antropologia pós-moderna atestou o quanto Boas traçou categorias indissociáveis para a cultura e para a arte, por entendê-las como "elements that seem to give continuity and depth to collective existence" (elementos os quais parecem dar continuidade e profundidade à existência

\footnotetext{
${ }^{6}$ Continua a se esperar se é possível derivar leis geralmente válidas as quais controeam o crescimento de estilos de arte específicas (...). Com o aumento da habilidade técnica e perfeição de ferramentas, as mudanças são inevitáveis de ocorrer. Seu curso é determinado pela história cultural geral do povo. Não estamos em posição de dizer que as mesmas tendências, modificadas por acontecimentos históricos locais, reaparecem no curso do desenvolvimento da arte em toda parte (tradução dos autores).
} 
coletiva) (Clifford, 1988: 232), viu no autor de Primitive Art um proporcionador do princípio da pluralidade dos valores, da relatividade cultural e das formas menos rígidas de interpretar as artes. Inserindo Boas na perspectiva de situar a antropologia como meio de estabelecer uma renovação da estética, Clifford (1988) detectou o quanto este antropólogo enxergou, na deliberação dos padrões visuais e em suas relações com significados, um campo produtivo de reflexão e aproximação em relação aos fenômenos artísticos formais discutidos na Europa.

Outro ponto interessante é o levantado por Almeida (1998), para quem o antropólogo em questão transpôs um antigo limite de separação entre as artes e superou uma espécie de semântica superficial, implícita ao ponto de vista evolucionista. Para esta intérprete, além de pensar no quanto Boas fez do julgamento da forma técnica um julgamento estético, de maneira a garantir a autonomia da arte enquanto sistema significativo, ela também observou nas análises do antropólogo culturalista evidências não para buscar as origens das artes de povos tradicionais, mas para entender a maneira com a qual os princípios da forma, da simetria e do ritmo seriam agenciados e poderiam equivaler, inclusive, a uma dimensão que iria para além das fronteiras concretas do objeto (uma espécie de transmutação dos seres).

O discorrer boasiano sobre as artes trouxe para os debates das ciências sociais alternativas de ler experiências, práticas e significados (elementos os quais atuam como símbolos) no e para além do estado emocional da vida cotidiana (Boas, 1955). Ainda que privilegiasse uma noção sistêmica e sincrônica das culturas como entidades coesas e homogêneas (Hofbauer, 2009), seus questionamentos acerca do entendimento dos contextos de enunciação artísticos e, por conseguinte, de seus diversos processos e objetos evidenciaram continuamente a relevância para um espaço discursivo de representações e de fenômenos que ultrapassam a dimensão visual e estabelecem diálogos com significados antropológicos (Feldman Bianco \& Moreira Leite, 1998; Pellegrino, 2007).

\section{As Artes na Escola Francesa de Sociologia e na Estrutural Funcionalista}

O aparecimento da Escola Francesa de Sociologia não poderia trazer mais força ao Culturalismo Boasiano e às novas formas de entender as sociedades. Foi nesta 
conjuntura de transição para o pensamento moderno, segunda metade do século XIX, que o trabalho de Émile Durkheim e de pesquisadores como Lévy Bruhl e Marcel Mauss resultou, bem pontuou Cardoso de Oliveira (2003), em uma perspectiva atrelada a um método comparativo, porém subtraído do tempo como campo de suas preocupações, a fim de que o conhecimento sincrônico de outras sociedades e de suas representações coletivas tomasse o foco.

Lembrado o conceito de representações coletivas, tecido pelos próprios integrantes do grupo e necessário para situar o espaço de onde se iniciariam suas análises, e correspondente às maneiras pelas quais "o ser especial que é a sociedade pensa as coisas de sua experiência própria” (Durkheim, 1968: 621), devemos ressaltar que a Escola Francesa de Sociologia se estabeleceu, desse modo, como um grupo teórico não passível de maiores aproximações com a psicologia, em virtude deles próprios construírem seu espaço de interpretações ancoradas no racionalismo francês um espaço no qual a teoria poderia desempenhar um papel de interesse para a sociedade (Lévi-Strauss, 1974). A Escola Francesa de Sociologia, sob o mote de configurar uma linha teórica particular, ativou outra faixa de debates sociais os quais se estenderiam para geografias diversas e marcaria, profundamente, as maneiras de se ver culturas, artes e indivíduos.

O caso de Marcel Mauss, cuja obra é menos sistematizada que a do seu tio Émile Durkheim, chama a nossa atenção por mostrar, não somente, uma reformulação "das questões colocadas por Durkheim no único campo em que são passíveis de serem respondidas, o da natureza do simbólico e de sua ligação com a obrigação de dar" (Caillé, 1998: 06), mas por desvelar este interesse nas artes como campo fecundo de análises culturais. Segundo apontado por Mauss (1972), as artes seriam, por definição, objetos reconhecidos como tais por um grupo, de maneira que sob o olhar estético e semiótico do autor, ao lado do de Franz Boas, veríamos alguns dos relevantes acessos para o universo das artes via ciências sociais.

Em suas discussões sobre uma estética antropológica, este estudioso em foco demonstrou uma proximidade de leitura com a filosofia alemã, como é o caso da filosofia kantiana e hegeliana e de aspectos da própria fenomenologia. Igualmente tributário deste pensamento filosófico via Octave Hamelin ${ }^{7}$, assim como outros integrantes da Escola Francesa de Sociologia, Mauss ainda teve sua originalidade ao

\footnotetext{
${ }^{7}$ Segundo Cardoso de Oliveira (1983), Octave Hamelin foi o principal mediador entre a filosofia alemã e a École Française de Sociologie, através da obra Essai sur les Éléments Principaux de La Représentation.
} 
detectar na multidisciplinaridade da antropologia uma chave de entendimento para o universo, segundo ele, psico-fisiológico das produções sensíveis (Mauss, 1972).

No que concerne as suas compreensões para o mundo das artes, o intelectual tencionou uma contextual correlação com a Crítica da Faculdade do Juízo (1793), de Immanuel Kant. Destacando buscar para grupos sociais um estudo gnosiológico da sensação e de suas formas apriorísticas de espaço e tempo, bem tangencial ao proposto por Alexander Gottlieb Baumgarten em Meditações Filosóficas Sobre as Questões da Obra Poética (1735), a abordagem de Mauss tratou de se paralelizar com os quatro paradoxos fundadores do juízo de gosto kantianos, para dar visibilidade e independência às artes das diversas comunidades globais quanto aos seus pressupostos metafísicos, éticos, científicos, religiosos, morais, em outras palavras, quanto aos elementos culturais de suas legitimações (Nunes, 2010).

Seriam, neste enredo, então:

01. A Satisfação Desinteressada: tida por uma caracterização de se algo é belo ${ }^{8}$, mas que "não se quer saber se a nós importa ou sequer possa importar algo da existência da coisa" (Kant, 2012: 40), este paradoxo pôde ser detectado nas abordagens de Mauss quando destacou que "o objeto estético é um objeto que se pode contemplar; há no fato estético um elemento de contemplação, de satisfação fora da necessidade imediata, uma alegria sensual, mas desinteressada" (Mauss, 1972: 94);

02. A Subjetividade Universal: referente à como nós proferimos juízos geralmente válidos, despretensiosos e unânimes - e aqui o juízo sobre o belo imputa a qualquer um a complacência no objeto, sem, contudo se fundar sobre um conceito -, este paradoxo se firmou "em torno de juízos estéticos sobre um objeto simplesmente com respeito à relação de sua representação com sentimento de prazer e desprazer" (Kant, 2012: 50). Mauss tangencialmente detectou que todas as populações exerciam uma faculdade de sensibilidade pura reconhecível e ancorada em uma complacência estética;

03. A Finalidade sem Fim: associado a quando "não é porventura pensado o conhecimento de um objeto, mas o próprio objeto (a forma ou existência do mesmo) como efeito, enquanto possível somente mediante um conceito último" (Kant, 2012: 57-

\footnotetext{
${ }^{8}$ Devemos salientar que o belo para Kant, associado à imaginação e livre da necessidade de produzir conceitos, abre a possibilidade do universal, por surgir de maneira desinteressada, ao passo que o agradável, contextual e, portanto, não universal, é ligado diretamente ao estatuto do interesse (Kant, 2012).
}

Iluminuras, Porto Alegre, v. 15, n. 35, p. 11-43, jan./jul. 2014 
58). Mauss, de maneira correlacional, verificava que as artes desempenhavam um papel reconhecido "pela presença de uma noção mais complicada que a simples noção de utilidade" (Mauss, 1972: 93);

04. A Necessidade Livre: por saber que um juízo de gosto possui "um princípio subjetivo, o qual determina, somente através de sentimento e não de conceitos, o que apraz ou desapraz" (Kant, 2012: 81); ou ainda perceber que o julgamento de gosto requer uma adesão mais do que uma obediência (Cauquelin, 2005; Nunes, 2010), para Mauss, as artes igualmente se estabeleciam no patamar de artigos de luxo, desnecessários, geralmente conectados por um sentimento, porém sem qualquer aspecto coercitivo.

O antropólogo sobressaía, nesse entendimento, ainda a necessidade absoluta de se mapear as artes plásticas. Mesmo reconhecendo que já havia uma parcela da tipografia artística constantemente estudada, outra, dentro do pressuposto de serem técnicas mais estéticas que as técnicas por si sós, ainda requeriam por olhares canonicamente mais destituídos.

É o conjunto dos contatos tipológicos que permite que se tracem conjuntos de civilizações ou camadas sucessivas e filiações de civilizações. Mas é preciso procurar ao mesmo tempo o que singulariza uma época ou uma sociedade: o estudo de elementos comuns e o estudo de elementos divergentes ou singulares devem ir a par. A imagem da arte de uma sociedade deve ser construída no seu todo, com seus caracteres próprios: é preciso fazer um retrato individual (Mauss, 1972: 96).

Outro aspecto não menos relevante é o que o antropólogo levantou acerca de uma abstração sensível presente, inclusive, nas chamadas artes não ideais (nas que compreendiam objetos, utensílios, padronagens decorativas etc.). Esta separação, ocorrida naquele contexto por uma concepção crítica de Baudelaire sobre a modernidade (1996), e que privilegiava as formas de arte europeias e ideais (pintura, escultura, desenho e arquitetura), deveria ser revista para, assim, não implicar em qualquer tipo de excludência simplória.

Ressaltado o inconsciente de povos não europeus, presentes em suas tradições coletivas, seguir outra lógica de apresentação, porém não menos sensível e significativa, Mauss (1972) observou não somente o fato de não sabermos em que medidas as artes tinham sido feitas para que elas ganhassem o crédito de artísticas, bem como ressaltou o quanto nossa concepção de arte era um enunciado construído e que precisava ser estranhado naquele momento. 
Uma linha de pensamento muito influenciada pela Escola Francesa de Sociologia, em termos de análise cultural, e representativa para este momento de transformação do conhecimento social foi a do Paradigma Estrutural-Funcionalista. Também destacável por tecer críticas aos próprios centros acadêmicos da Inglaterra, ainda atrelados a linhas de pensamento "evolucionistas", o presente paradigma trouxe, no início do século XX, algumas das vozes mais importantes para a história do debate antropológico e para os futuros novos erros e acertos das pesquisas sociais.

Emergente nesse mover-se entre crise de confiança e certezas do próprio sistema, a estratégia estrutural funcionalista já não buscava separar as sociedades entre centro e periferia, uma vez que não seria mais a Europa e seus costumes o centro das racionalidades, mas as próprias localidades estudadas. O plano deste grupo, imerso em uma prefiguração relativista, tratava de outro tipo de comparação, no qual a sociedade do observador, não mais um modelo acabado para onde as outras deveriam se destinar, figurava como outro dado sobre a sociedade e as relações entre povos (Da Matta, 1983).

Algumas décadas mais tarde, quando do aparecimento, nas universidades inglesas e americanas, de abordagens culturais problematizadoras quanto aos centros de saber hegemônicos, também conhecidas por perspectivas pós-coloniais e dos estudos culturais ingleses, vimos interessante cogitar uma relação indireta com as primeiras rachaduras advindas da descentralização de saber a partir deste grupo inglês de antropólogos. Seja por compreendermos que certas modificações na história causam reverberações contínuas em tempos posteriores (Thompson, 1997; Le Goff, 2010), o espaço de propagação de novas linhas de análise para os campos da cultura e das artes, em tempos mais recentes, bem ganha coerência ao observar ruídos científicos também em nomes como de Radcliffe Brown e de Raymond Firth, entre outros atrelados a este paradigma.

Para o caso contextual de Radcliffe-Brown (1980) no Paradigma Estrutural Funcionalista, envolvido com o estudo de populações tradicionais, as tarefas dos antropólogos podiam pedir por abordagens distintas. Uma delas, denominada histórica, buscava explicar a existência de uma característica típica de uma sociedade específica, resultado de uma sequência de eventos próprios a essa sociedade, enquanto a outra, comparativa, procurava não 'explicar', mas compreender particularidades de sociedades, de forma a vê-las, inicialmente, como casos peculiares de uma classe ou espécie geral de fenômenos sociais. Na ocorrência de peculiaridades detectadas, as 
mesmas poderiam, depois, ser relacionadas a certas tendências comuns, preferencialmente universais das sociedades humanas. Para a escolha das opções mencionadas anteriormente, cabia ao antropólogo decidir pela abordagem (ou método) que melhor se adequaria a sua comunidade em foco.

Todavia, por apresentar limitações decorrentes da exclusão do conceito de tempo, o qual havia sido colocado em suspenso em nome da defesa de um conhecimento objetivo, alguns representativos integrantes da Escola Funcionalista acabaram por expulsar o indivíduo, a subjetividade e a história como objetos de investigações (supressões ocasionadas pelo fato do horizonte da disciplina ser ameaçado por uma chamada perspectiva especulativista) e mostraram inegáveis restrições para ler os fenômenos sociais e suas representações em análises igualmente diacrônicas (Melatti, 1978). De certa forma, essa postura adotada trouxe contraditoriamente aos objetivos do grupo, uma impossibilidade de se pensar relacionalmente a cultura e as artes, já que as mesmas não poderiam ser tangenciadas sem uma polissemia discursiva e multitemporal que lhes cabia.

A exemplo dessas restrições, no caso mais específico de Radcliffe Brown, ainda foi evidenciado que

O termo cultura aparece raramente nos seus trabalhos. [...] Sua principal preocupação é combater a reificação desse conceito. Desde logo afasta a ideia de que cultura possa englobar objetos materiais, bem como evita também dizer que a cultura 'afeta' os indivíduos de certa maneira ou 'age' sobre eles. Para RadcliffeBrown, uma cultura seria uma descrição dos modos padronizados de se comportar: de pensar, de sentir e de agir. [...] Radcliffe-Brown conclui que não pode existir uma ciência da cultura, pois, uma vez que uma cultura é sempre característica de um sistema social, seu estudo é englobado pela ciência dos sistemas sociais (Melatti, 1978: 22-23).

Apesar das contradições, alguns dos autores da Escola Funcionalista, entre eles Radcliffe Brown, Evans-Pritchard e Raymond Firth se viram empertigados na criação do Guia Prático de Antropologia, cujo um dos temas tratava sobre o universo das artes. Válido para montar um olhar para a época, este guia, mesmo superficialmente, via um ponto pertinente nas experiências visuais, pelo fato das mesmas serem fontes de informações sobre os problemas de invenção e difusão culturais, bem como pelo fato deste campo da produção sensível deter a importância de mostrar diferentes técnicas, artefatos e práticas em relação à totalidade das suas organizações sociais (Guia Prático de Antropologia, 1971).

Iluminuras, Porto Alegre, v. 15, n. 35, p. 11-43, jan./jul. 2014 
O guia funcionalista destacava, por exemplo, o papel dos materiais naturais disponíveis para a configuração concreta de uma arte típica de uma cultura ou de uma área, de maneira que o mesmo não indeferia a possibilidade de formação de diálogos estéticos entre sujeitos de suas próprias circunscrições e de outras estrangeiras (e aqui se inclui a formação de tradições visuais e de mestres nas expressividades plásticas). Particularmente interessados em investigar os significados das artes a partir da interlocução com os sujeitos observados, seus métodos de acesso ao universo do outro, muitas vezes, se encerravam em uma série de análises regularmente simplistas e descritivas, possíveis de causar controvérsias por seus aspectos demasiado formalistas e pouco flexíveis em vias de fato (ver Figura 02).

\section{A}
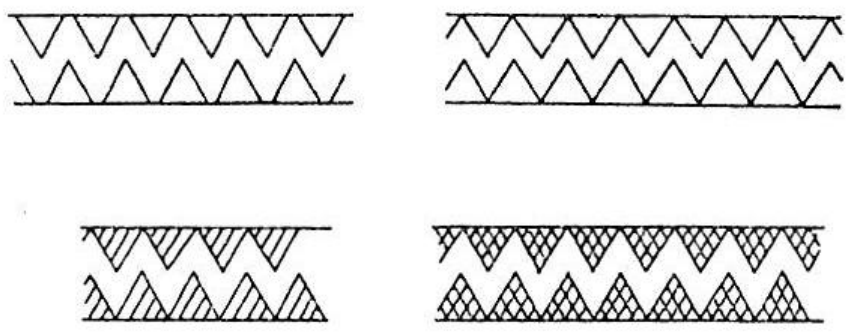

B
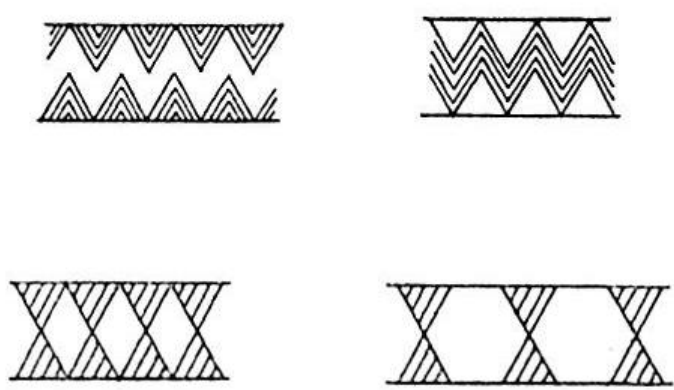

Figura 02. O Guia Prático de Antropologia sugeria que as padronagens visuais, para além de seus significados simbólicos, deveriam ser descritas de acordo com seus motivos geométricos, sem maiores implicações psicológicas ou semióticas. Fonte: Guia Prático de Antropologia, 1971: 378.

A saída do discurso e da subjetividade nos sujeitos e na dimensão das artes acabou por invalidar estes últimos como perene de significados e criou possíveis ecos nas maneiras com as quais a antropologia poderia dialogar com seus percursos psicológicos e sensíveis (uma espécie de retrocesso para encarar indivíduos e experiências visuais 
diferentes). Por simplesmente privar a validação do enunciado para o caso de proposições artísticas, o Guia Prático de Antropologia também descartou a nuance do inconsciente, defendida por Mauss (1972), e transformou a experiência sensível em algo que seria exprimível por uma fórmula previsível.

Mesmo tendo a Escola Francesa de Sociologia como influência declarada, este material funcionalista não seria um indicativo para observar diálogos semelhantes com a filosofia alemã, de maneira a pensar nestes filósofos como campo para o estudo de outras culturas não diretamente ligadas aos modelos de vida e de experiência artísticos europeus. Infelizmente, também em virtude das informações contidas no Guia Antropológico não apresentarem maiores extensões dos seus pensamentos em torno da arte e nem sobre possíveis rastros para um conhecimento mais denso de suas compreensões estéticas, análises maiores sobre o papel das artes neste contexto se viram inconclusas.

Um estudo mais denso foi apresentado por Raymond Firth (1992) em uma publicação posterior, já no livro Anthropology, Art, and Aesthetics, organizado por Jeremy Coote e Anthony Shelton. Responsável por estabelecer relações, de maneira mais específica, entre as artes e a antropologia, o ensaio do intelectual, mesmo articulado com contextos e linhas de entendimentos mais contemporâneos, é um dos mais completos documentos para se analisar abordagens antropológicas para as artes, sob o olhar de alguém que fez parte e reprocessou sua gênese estrutural funcionalista.

Firth, envolto na problemática de investigar os princípios da estética, para além daqueles apregoados pelas associações à beleza e às belas artes europeias, desvelou uma impossível noção de consensualidade até para este debate interdisciplinar em questão, visto um número considerável de olhares imprimirem as mais variadas opiniões. Foi neste ensaio, direcionado para refletir sobre a riqueza e a variedade que abarca o assunto das produções visuais, que o autor apontou, não obstante, para o fato do diálogo entre os campos da antropologia e das artes, mesmo potencial no começo das ciências sociais modernas, aparecer mais concretamente somente no período das décadas de 1950 e 1960, já tomado por uma característica plurivocal e plurimetodológica - diálogo este deveras atrelado a sociedades não desenvolvidas tecnologicamente, com pesquisadores como, por exemplo, Franz Boas, Alfred Gell e Edmund Leach (Coote \& Shelton, 1992; Firth, 1992).

Para o intelectual, a concepção antropológica de arte, compartilhada igualmente por Alfred Gell (1992), deveria ser destituída daquela ligada aos discursos disciplinares 
da disciplina Estética. Muito mais interessado por construir uma antropologia da estética a partir de localidades particulares e de seus entendimentos ontológicos fundamentais, Firth buscou a filosofia do gosto, a qual empreendia uma gama de discursos morais concernentes à transcendência, à Verdade e ao Bem, para traçar o que para ele poderia se chamar de uma teologia da arte (Firth, 1992).

\begin{abstract}
Much modern anthropology of art has been concerned not only with explicit but also with implicit meanings - relationships which the people themselves do not, possibly cannot, formulate in words, but which are of prime importance for an understanding of the origin and maintenance of their art. One general theory of symbolic behavior, including the creation of things classified as art, assumes the existence and operation of psychological processes of which the person concerned are quite unaware in any conscious sense (Firth, 1992: 25) ${ }^{9}$.
\end{abstract}

Por levantar um debate sobre as artes que aceitasse um estranhamento das nossas próprias certezas acerca de seus domínios, Firth foi um grande aliado para introduzir o entendimento do que seria diferente e poderia requerer ângulos de fora dos nossos lugares habituais. Mesmo muito aproximado, em aspectos gerais, do relativismo visual empreendido por Franz Boas e Marcel Mauss, diferente do então proposto pelo Guia Prático de Antropologia Estrutural Funcionalista, Firth tem sua importância por também traçar uma etnografia do pensamento antropológico para as artes e observar um interesse que viria ganhar, cada vez mais, espaço no território interdisciplinar da contemporaneidade.

\title{
As Artes na Escola de Cultura e Personalidade e no Estruturalismo Lévi- Straussiano
}

O chamado Paradigma Culturalista Boasiano, o qual tratou de manter um esforço constante de interpretação das diferenças culturais entre os grupos humanos, manteve-se prenhe de indagações e adotou relevantes rumos para um debate entre artes e antropologia menos explícito.

Atentado o fato de que o estudo da cultura tinha sido praticado de forma demasiado abstrata, não tendo sido pormenorizado os vínculos que existiam entre

\footnotetext{
${ }^{9}$ Uma grande parcela da Antropologia moderna da arte tem se preocupado não só com explícitos, mas também com significados implícitos - relações que as próprias pessoas não fazem, e possivelmente não podem, formular em palavras, mas que são de suma importância para a compreensão da origem e manutenção de suas artes. Uma teoria geral do comportamento simbólico, incluindo a criação de coisas classificadas como arte, pressupõe a existência e funcionamento dos processos psicológicos de que a pessoa em causa é completamente inconsciente, em qualquer sentido consciente (tradução dos autores).
} 
indivíduos e suas culturas (Cardoso de Oliveira, 2003), a partir da década de 1940 uma nova geração de antropólogos filiados à perspectiva boasiana, que fícou emblematicamente conhecido como Escola Cultura e Personalidade, se dedicou a compreender como seres humanos viviam as culturas e como estas poderiam ser parcialmente absorvidas, inclusive, pelo campo das suas produções artísticas.

Formada por pesquisadores e ex-alunos, em sua maioria, advindos do grupo do próprio antropólogo Franz Boas, a Escola Cultura e Personalidade passou a observar como a cultura não podia existir enquanto realidade "em si", ainda que ocorresse uma relação de independência desta com outros grupos culturais. Em meio a estes novos dilemas, ela passou a buscar as formas de presentificação cultural nos sujeitos sociais (e aqui se incluem as diversas formas de se pensar sensivelmente), e que poderiam ilustrar, coerentemente, condutas, ações e performances sociais; possibilidades reais as quais permitiam uma melhor compreensão das descontinuidades entre as diferentes culturas (Cuche, 2002).

Para os intelectuais egressos desta escola, o ponto fundamental se relacionava quanto ao questionamento de quais mecanismos de transformação sujeitos de origens semelhantes poderiam formular diferentes tipos de personalidade, característicos de determinados grupos particulares. É nesse contexto, e pelo que poderia também ser absorvido do universo do cinema, das artes plásticas, da música e da literatura que Ruth Benedict, aluna e em seguida assistente de Boas, foi fortemente dedicada.

A definição dos "tipos culturais", conjunto de orientações gerais e escolhas significativas que determinados grupos sociais fazem dentre as opções que lhes são possíveis em contextos primeiros (Benedict, 1983), foi uma de suas grandes contribuições e fez com que o culturalmente próximo passasse a ganhar contornos peculiares e arbitrários, ao passo que o culturalmente distante, lógico e previsível por toda uma criação artística e cultural dos centros hegemônicos, pudesse ser repensado e colocado sob a ótica de sua ontologia - algo que Geertz (2009) chamou de a "nativização de si mesmo". A visão da autora buscava ilustrar que mesmo os indivíduos hábeis de realizar ações individuais, seriam precedidos por modelos socialmente convencionados pelo "costume do grupo", de maneira que, então, a cultura seria obtida pela socialização, daí sua percepção sobre uma "personalidade cultural" ou um ethos de vida no grupo (Benedict, 2002). De certa forma, esta seria uma ideia de que a cultura atuaria como um agente superior e independente dos membros da sociedade, o que a aproximaria de uma percepção, ao menos em termos iniciais, estrutural funcionalista. 
Tida por ser uma autora que transitou em sua obra não por um tipo de descrição, mas um distintivo de redescrição, Benedict empregou uma técnica interpretativista de fontes, até então, menos utilizadas para a antropologia (produções sensíveis), visando evidenciar contrastes. Dessa forma, naquele cenário tido como contrário perene das populações distintas quanto a sua, a antropóloga buscou desmistificar o elemento exótico neles encontrado, o que incorreria mais em uma ordem de experiência moldada pelos costumes do ambiente que cerca o indivíduo (Benedict, 1983; Geertz, 2009).

Como a própria autora observou:

\begin{abstract}
Não há ninguém que veja o mundo com uma visão pura de preconceitos. Vê-o, sim, com o espírito condicionado por um conjunto definido de costumes, e instituições, e modos de pensar. Nem mesmo nas suas concepções filosóficas ele consegue subtrair-se a esses estereótipos; até os seus conceitos do verdadeiro e do falso são ainda referidos aos seus particulares costumes tradicionais. [...] A história da vida individual de cada pessoa é acima de tudo uma acomodação aos padrões de forma e de medida tradicionalmente transmitidos na sua comunidade de geração para geração. Desde que o indivíduo vem ao mundo, os costumes do ambiente em que nasceu moldam a sua experiência dos fatos e a sua conduta (Benedict, 1983: 14-15).
\end{abstract}

De certa forma, para Benedict, um exercício de entendimento pleno do outro só podia partir dessa concepção de colocar em suspeito as nossas próprias categorias de entendimento, visto ocorrer uma estandardização ocidental de lógicas, práticas e condutas sociais. E se a arte poderia servir como parceira na aproximação de sensibilidades distintas, uma dimensão espiritual de indivíduos que podia facilmente fugir de uma análise cultural, melhor seria. Desde os primórdios da existência humana, observou a autora, o homem foi um habitante de uma província que se isolou por meio de altas barreiras (Benedict, 1983) a tal ponto que, já sob a caracterização "moderna", mantém uma atitude separatista e de uma longa continuidade histórica entre aqueles que ele julga como os seus dos estrangeiros.

Dentro dessa dialética, seria possível entender que um determinado complexo cultural se definia não pela ausência ou pela presença de dado elemento ou dado complexo de traços culturais, mas pela orientação global da cultura que requer um entendimento questionador de seus saberes e práticas de ordem filosófica, artística e espiritual. Com uma visão contrária ao evolucionismo e darwinismo social, Ruth Benedict (1983) deflagrou como a pluralidade das culturas e das sociedades, não monolíticas e encontradas em diferentes estágios de desenvolvimento, deveriam ser 
lidas enquanto entidades autônomas, onde cada cultura moldaria as ações, emoções e socializações dos seus sujeitos.

Lévi-Strauss foi outro autor relativamente contextual a esse período (sua maior dedicação ao método estruturalista ocorreria na década de 1950) e que traçou uma reverberante série de pensamentos sobre as sociedades, as culturas e as artes. Adepto da noção de que "a totalidade dos costumes de um povo sempre forma um todo ordenado, um sistema" (Geertz, 2004: 124), o antropólogo, influenciado pela Escola Francesa de Sociologia, buscou a linguística como modelo de entendimento e tratou de se perguntar não quanto ao que seria cultura e sociedade, mas onde começaria o homem e a sociedade (Lévi-Strauss, 1985).

Embalado por uma visão difusionista dos costumes e culturas, onde "as sociedades humanas, como os seres humanos individualmente, jamais criam a partir de um tecido inteiro, mas simplesmente escolhem certas combinações de um repertório de ideias disponíveis" (Geertz, 2004: 124), Lévi-Strauss encarava que o valor cultural seria dado pelo grupo, tal como a gramática de uma língua, visto a ordenação de uma gramática seguir uma disposição semelhante.

[...] pode-se também tratar a linguagem como condição da cultura, e por duplo motivo: diacrônico, visto que é sobretudo através da linguagem que o indivíduo adquire a cultura de seu grupo; instrui-se, educa-se a criança pela palavra; ralha-se com ela, lisonjeia-se com palavras. Situando-se de um ponto de vista mais teórico, a linguagem aparece também como condição da cultura, na medida em que esta última possui uma arquitetura similar a da linguagem. Ambas se edificam por meio de oposições e correlações, isto é, de relações lógicas. Tanto se pode considerar a linguagem como um alicerce destinado a receber as estruturas às vezes mais complexas, porém do mesmo tipo que as suas, que correspondem à cultura encarada sob diferentes aspectos (Lévi-Strauss, 1985: 86).

O processo de socialização, o qual transportaria o indivíduo de uma condição da natureza para outra, estrutural, seria condicionado pela internalização de regras e convenções sociais, de maneira a oferecer um caráter de sistema capaz de explicar todos os fatos observados (Lévi-Strauss, 1985). Sob este aspecto, por exemplo, que falar de natureza humana, para o autor, incorreria em algo incerto, visto o adquirido e o inato estarem misturados.

Este entendimento das regras como componentes da vida em sociedade trouxe, bem devemos demarcar, um caráter interessado por buscar os alicerces que fundariam a vida social e as normas que possibilitariam a criação de significados culturais. Os pressupostos da análise estrutural lévi-straussiana trafegaram pela busca das estruturas fundantes da sociedade, pela dedução de seus princípios subjacentes (seu nexo) e 
finalmente pela chegada à lógica universal da comunicação humana, para, nesse sentido, conforme evidenciado pelo próprio antropólogo, observar que ao sujeito "primitivo" caberia a criação de referências sistêmicas a partir de eventos (mitos), ao passo que ao sujeito moderno caberia a criação de inventos a partir de abstrações (estruturas), criadoras de realidades e interferentes no real (Lévi-Strauss, 1982).

Muito aproximado de Ruth Benedict quanto à atenção ao campo psicológico de sujeitos, e de como estes campos influenciavam sistemicamente nas suas formações e nas das sociedades, Lévi-Strauss dialogou com as artes e viu nelas como exemplificar suas propostas teóricas. Por entendê-las como operações de signos e não de conceitos, daí sua proximidade com o pensamento mítico e com a função da arte de significar objetos, o antropólogo francês enxergava nos processos artísticos uma forma de conhecimento, assim como a ciência, indispensável aos mapeamentos dos sistemas de significação existentes (Lévi-Strauss, 1985) - as artes seriam, portanto, modelos reduzidos ${ }^{10}$ da natureza, geradoras de contiguidade entre mundo natural, corpo e intelecto (Lotierzo, 2013).

\begin{abstract}
Para Lévi-Strauss, a arte situa-se entre a ciência e o mito. Enquanto o pensamento mítico opera com signos, elaborando estruturas a partir de resíduos de acontecimentos, a ciência, pelo contrário, emprega estruturas intelectuais como instrumentos para a confecção de eventos. $\mathrm{O}$ mito faz um protesto constante contra a falta de significado, nutrindo-se sempre da ilusão ou da vontade de escapar da história; a ciência aspira ao conhecimento, e não, como o mito, ao significado (Lopes Pontes, 2010: 02).
\end{abstract}

Por se estabelecerem como linguagem e em um meio caminho entre o intelecto e o sensível, as artes desempenhariam o papel de suscitar uma emoção estética, já que fariam deslocamentos de objetos não-significativos para o patamar de significantes. É nesta concepção, mais especificamente, que o antropólogo evidenciou como suas análises para as artes de localidades pertencentes ao eixo urbano ocidental seriam encontradas no nível da ocasião, visto a concepção e o planejamento serem interiores e exteriores ao fazer artístico, de grande importância para o ato criador, ao passo que a emoção estética de populações mais tradicionais poderia ser encontrada no nível da execução, uma vez que o artista e o material com o qual ele trabalha estariam

\footnotetext{
${ }^{10}$ De acordo com Lévi-Strauss (2008), o modelo reduzido implicaria na reprodução da natureza em um objeto. Suas dimensões seriam simplificadas, de acordo com os limites impostos pela técnica, suporte e materiais adotados.
}

Iluminuras, Porto Alegre, v. 15, n. 35, p. 11-43, jan./jul. 2014 
diretamente ligados, e o ato criador seria inseparável do fazer social. No caso das artes aplicadas, a propósito, a ênfase poderia ser encontrada em um terceiro nível, no da finalidade, visto o ato criador ser posterior e extrínseco, ligado aos aspectos funcionais da peça (Passetti, 2008).

Embora Lévi-Strauss não tenha extrapolado suas fronteiras quanto à sua interpretação de como as artes eram concebidas - para ele, estas surgiam primeiro no plano das ideias para só depois ganharem suas materializações, atuando em um papel comunicativo ou coletivo (Lévi-Strauss, 1985) -, fica evidenciado que o mesmo se posicionava como um estruturalista ${ }^{11}$ quanto às artes de populações tradicionais, ao passo que se portava como um crítico no que concerne às artes dos centros europeus ponto este possivelmente alimentado por um histórico com seu bisavô, regente de uma pequena orquestra, e seu pai, formado em Belas Artes e grande entusiasta para levar o filho a museus e exposições (Souza \& Goldstein, 2008).

Preocupado com o academicismo dos centros artísticos da Europa, ou mesmo com as exigências figurativas destes centros de se pintar como os grandes mestres, motivo pelo qual estas artes plásticas modernas tinham sofrido uma individualização considerável e um consequente enfraquecimento das suas funções significativas (Lopes Pontes, 2010), Lévi-Strauss via no Impressionismo e no Cubismo, cada um à sua maneira, uma oportunidade de crítica e de retorno à dimensão significativa perdida pelas produções sensíveis, de forma a evidenciar como estas artes, a partir das revoluções modernas, ratificariam transformações as quais afetariam não apenas os seus universos criativos, como também aspectos nas sociedades como um todo (LéviStrauss, 2008; Lotierzo, 2013).

O Impressionismo, por exemplo, ganharia destaque para o autor por ser um movimento que fez com que a arte não somente mudasse de estilo (efeito vislumbrado em termos de menos naturalismo, em prol de uma instantaneidade capaz de pegar pictoricamente os efeitos de luz e sombras variantes no decurso do dia), mas também de tema. Muito voltado para como o homem poderia se relacionar com as mudanças advindas da Revolução Industrial e de uma perda de natureza ainda retratada nos séculos XVII, XVIII e XIX, o Impressionismo era, para Lévi-Strauss, alternativa de guia para se explorar e visualizar o terreno transitório dos seus tempos contextuais

\footnotetext{
${ }^{11} \mathrm{O}$ que caracteriza o entendimento de Lévi-Strauss em torno das estruturas é a noção de transformação. Seria estas estruturas um sistema, regido por uma coesão interna, de maneira que a observação da coesão ocorreria em face aos estudos das transformações de um sistema isolado (Lotierzo, 2013).
} 
(Lévi-Strauss \& Charbonnier, 1989), mesmo tendo se fixado mais na representação (o sensível) e se descuidado da significação (o inteligível).

O Cubismo, por conseguinte, iria além da ruptura Impressionista, visto reencontrar a dimensão semântica da arte, não lhe bastando mais somente representar, porém significar. E embora o Impressionismo tenha transformado parte da relação artística do homem com a natureza, o Cubismo então a eliminou por completo de suas preocupações pictóricas e trouxe como consequência uma ênfase em valores puramente decorativos (vide as obsessões de Braque com o espaço e de Picasso com a forma). Segundo o autor, esta preocupação mais decorativa e espacial, mesmo ainda individualista e, portanto, destituída da função coletiva da obra de arte, seria um indício da natureza já não fazer mais parte do cotidiano do homem, senão como entidade transformada e dominada (Lévi-Strauss \& Charbonnier, 1989; Lopes Pontes, 2010) motivo este pelo qual o Cubismo, para o autor, se mostrava incapaz de provocar emoção estética (Lotierzo, 2013).

Destacável por ser um dos primeiros antropólogos a olhar diretamente tanto para os circuitos canônicos das artes plásticas nos eixos europeu e americano, quanto por se debruçar nas artes produzidas por localidades adjacentes a esses centros hegemônicos, Lévi-Strauss marcou o pensamento antropológico moderno, possibilitou à antropologia algumas das primeiras reflexões sobre a transformação das artes plásticas europeias a partir de conflitos internos a elas, bem como problematizou como estas mesmas artes constituíram um discurso mais sobre seus territórios particulares do que sobre o mundo.

Embora não aberto quanto às novas formas de criar significação para as artes, visto entendê-las, então, mais por um patamar de auto-referencialidade, o que as distanciava do coletivo e dos significados partilhados por todos os grupos sociais, o mesmo também não compartilhou de um olhar mais flexível sobre a dupla articulação da arte entre cultura e natureza (Lotierzo, 2013), porém reinscreveu um interesse pelas artes no cerne da antropologia.

\section{Uma Dimensão Interpretativa e Densa das Culturas e das Artes}

Para muitos, o horizonte de eventos desembainhado pelo Paradigma Interpretativista é de uma abordagem clássica, porém continuamente atual para se 
amparar reflexões antropológicas em torno dos entendimentos de sociedade, cultura e artes - motivo este pelo qual aqui merece uma análise mais apurada. Forjado a partir percursos filosóficos de autores como Heidegger, Dilthey, Gadamer, Ricoeur, entre outros, seu pontapé inicial se deu na antropologia americana de Clifford Geertz (2011), com suas novas estratégias de entendimentos intersubjetivos.

A abordagem geertziana, pensada como uma interiorização do tempo, quebrou com as limitações do sujeito cognoscente, ainda estático e intocável por uma realidade movente, e inaugurou uma investida em defesa direta da contextualização do conhecimento (Cardoso de Oliveira, 2003). Diferentemente dos enfoques que tinham por base o ponto de vista estruturalista (e aí podemos começar a problematizar, inclusive, as noções de identidade étnica, em prol de abordagens mais dinâmicas), as implicações da antropologia deste autor americano falaram sobre a impossibilidade de uma explicação básica, formal e preliminar dos códigos, sintaxes ou sistemas de signos, e trouxeram uma interpretação que buscava fundir o conceito de cultura e de sistemas simbólicos do antropólogo e do outro - os campos semânticos passíveis de leituras a partir de uma trama relacional (Cardoso de Oliveira, 1986).

\begin{abstract}
O que chamei há pouco de interiorização do tempo não significa outra coisa que a admissão tácita pelo pesquisador hermeneuta de que a sua posição histórica jamais é anulada; ao contrário, ela é resgatada como condição do conhecimento. Conhecimento que, abdicando de toda objetividade positivista, realiza-se no próprio ato de 'tradução'. (...) Indica a transformação da história exteriorizada e objetivada em historicidade, viva e vivenciada nas consciências dos homens e, por certo, do antropólogo. A fusão de horizontes implica que na penetração do horizonte do outro, não abdicamos de nosso próprio horizonte (Cardoso de Oliveira, 2003: 21).
\end{abstract}

Caberia dizer, por sinal, que foi a partir deste paradigma em questão que ocorreu o início de uma reviravolta sem precedentes para o pensamento antropológico em voga, visto não haver como desconsiderar o fato de que o interpretativismo efetuou uma quebra e, mesmo soando um tanto dramático, a própria morte de parte da antropologia enquanto fazer moderno construído desde o século XIX. Campo frutífero para inaugurar uma série de diálogos e dissensões para o universo antropológico, a morte desta porção antropológica problemática para os novos tempos e uma consequente ressurreição mais hermenêutica, instauraram uma abordagem menos autoritária, abertura antropológica a eixos pós-modernos e pós-coloniais.

Um dos primeiros aspectos mais relevantes ocorreu pelo fato do interpretativismo de Geertz (2011) perceber que os alicerces antropológicos já não eram mais os mesmos 
e se apresentavam distintos e entremeados pelo dilema de leituras não tão reais quanto eram pretendidas outrora (ficções, em certo sentido). Sob uma proposição de pôr em alerta as próprias certezas do fazer antropológico, as leituras socioculturais tributárias de uma abordagem interpretativista se tornaram produtivamente controversas, capazes de restituir um novo encantamento ao exercer científico das humanidades e de se reformular como pensamento e ação a partir de novas bases de entendimento.

Como ressalvado pelas considerações geertzianas, as tentativas antropológicas de compreensão de contextos trouxeram para si uma fenomenologia dos significados, avaliação das conjecturas, um traçar de conclusões explanatórias a partir das melhores interlocuções e não a descoberta do Continente dos Significados e o mapeamento da sua paisagem incorpórea (Geertz, 2011). Foi por esta alvorada do questionar uma "fusão de horizontes" no exercício interpretativista (o encontro de duas culturas em bases conceituais transterritoriais, o intérprete e o outro), que verificar e interpretar não poderia, então, ultrapassar a condição mais própria das humanidades, que é a de ser consciente que imaginar uma realidade não quer dizer encontrá-la plenamente.

Nos termos dos problemas desvelados a partir desta espiral argumentativa em torno das construções verossimilhantes e antropológicas, os conflitos passaram a se basear nos chamados efeitos da verificação e do esclarecimento das interpretações. E, visto que tais conflitos não deveriam ameaçar o modo de argumentação antropológico, mas lhe dar um caráter holístico de diálogos - diálogos historicamente situados, os quais exteriorizam entendimentos móveis de transformações e (des)ordens -, vimos possível encarar não somente a antropologia a partir de um patamar menos feroz quanto à irrefutabilidade de nossas explicações, como buscamos nos alertar contra o poder da imaginação científica que nos leva ao contato com as vidas dos estranhos - ou, pelo menos, nos atentar para a prática de sacralizar preconceitos por autoridade ou sacralizar preconceitos por precipitação, comumente observados em diversos exercícios antropológicos (Gadamer, 1997; Geertz, 2011).

Metodologicamente, este material conhecido por denso, decorrente do método aplicado, passou a se basear na condição de que todas as esferas humanas seriam construídas historicamente e, portanto, sujeitas a padrões de juízo historicamente definidos. Por perceber que somente uma pequena parte dos estar-junto de nossos interlocutores seria apreensível, com suas estruturas superpostas de influências e 
implicações, o interpretativismo se viu capaz de acessar os meandros e os enfrentamentos que fazem parte das formulações organizacionais e caóticas das sociedades, de maneira a visualizar nas suas operacionalizações móveis às hierarquias estratificadas de estruturas significantes, os códigos estabelecidos em termos dos quais respostas são elaboradas (Geertz, 2011).

Vale destacar que esta noção de cultura, compreendida por ideação, mesmo inexistente como entidade racionalizável, e por instituição não física, mesmo desagregada de uma presentificação oculta, pôde, então, ser traduzida por documento de atuação pública que está para além de perguntas sobre seu status ontológico - para além de perguntas quanto à sua ontologia, visto que sua independência passou a ser garantida pela nova conjuntura das ciências sociais e pelas formas plurais de dar conta da diversidade do mundo humano enquanto ação e existência efetivas. E constatada a máxima de que reflexões e análises trazem mais perguntas do que respostas, as implicações embaladas pelo presente entendimento de que compreender cultura é também compreender um contexto - contexto no qual se buscam formas de descrição inteligíveis para falar sobre a normalidade de tempos e espaços, sem dirimir particularidades -, o interpretativismo apresentou formas beneficamente inclusivas e, portanto complexas, de se pensar sociedades.

Uma das implicações mais visíveis detectou não haver como desconsiderar o fato de que as nossas interpretações não seriam outra coisa que não elas mesmas denominações particulares, reconstruções lógicas, significações dos acontecimentos. Também passíveis de ser tidas como de segunda ou de terceira ordem, já que o local de primeira ordem pertenceria ao próprio "nativo", ou enunciador cultural natural (Geertz, 2011), criou-se uma fenda na enunciação do discurso, de forma que minorias puderam tangenciar agendas antropológicas hegemônicas para reclamar seus papéis na construção de suas próprias leituras locais - alternativa de dirimir a autenticação de ficções errôneas criadas para suas formulações culturais.

Cabe demarcar o papel que a própria arte passou a revelar nesse reencantamento cultural da antropologia, uma vez que, conforme observado por Geertz (2008a), superamos parte de uma categoria de entendimento estruturalista e desapegada de modelos ditos canônicos e ocidentais, a qual era cabível muitas vezes entender objetos estéticos como um mero encadeamento de formas puras, para acolhermos outra mais 
fluida e que poderia trazer leituras da arte como fonte ${ }^{12}$, reflexão, desafio, descrição e parte da criação das energias específicas à dinâmica geral da experiência humana. Em outras palavras, a arte como expressão de sentimentos de povos pela vida.

Sob o pressuposto da arte por algo nunca totalmente intraestético, poderíamos examiná-la e interpretá-la a partir de um plano semiótico, ou, sob uma terminologia mais social, a partir de uma antropologia estética (algo também tangenciado por Firth, algum tempo depois, no seu ensaio do livro Anthropology, Art and Aesthetics). Muito Mais vinculada a olhares treinados em significação, ao contrário de patologia, seu raio de interlocução, para este campo antropológico, deveria ser feito com ideias e não com sintomas.

\begin{abstract}
Para que possa estudar a arte de forma eficaz, a semiótica terá que ir além do estudo de sinais como meio de comunicação, como um código a ser decifrado, e considerálos como forma de pensamento, um idioma a ser interpretado. O que necessitamos é [...] de um novo diagnóstico, uma ciência que seja capaz de determinar o sentido que as coisas têm para a vida ao seu redor. Os que elaborarem este diagnóstico terão que ser treinados em significação e não em patologia, e o tratamento terá que ser feito com ideias, não com sintomas (Geertz, 2008a: 181).
\end{abstract}

A título de exemplificação da arte contrárias a meros encadeamentos de formas puras, o antropólogo ilustrou seus argumentos com a relação profunda entre as linhas e as cores nas sociedades Yorubá e Abelam, além de aspectos contextuais para o entendimento da pintura italiana do Quattrocento e da poesia islâmica.

No caso mais específico das concepções visuais das populações Yorubá, localizadas na região do continente africano compreendida em uma parcela do território nigeriano e de áreas adjacentes, o uso das linhas nas suas construções visuais (Figura 03) puderam ser concebidos para além de significados meramente decorativos, visto tais mencionadas linhas surgirem como consequência de uma sensibilidade específica. Nesse caso, elas seriam atreladas a concepções de civilização (a noção de que um país com linhas em sua face sairia de uma condição natural) e de visibilidade das qualidades interiores abertas pelos destaques lineares (e aqui se incluem aspectos a respeito da profundidade, direção e comprimento das linhas, indicadores de linhagem, posição pessoal e status).

\footnotetext{
${ }^{12}$ Deve-se observar que a arte não é a única fonte de transmissão dos sentimentos que um povo tem pela vida, mas pode ser equivalente a outros, como é o caso da religião, moralidade, ciência, comércio, tecnologia, política, formas de lazer, direito e até a forma em que indivíduos organizam vida prática e cotidiana (Geertz, 2008a).
}

Iluminuras, Porto Alegre, v. 15, n. 35, p. 11-43, jan./jul. 2014 


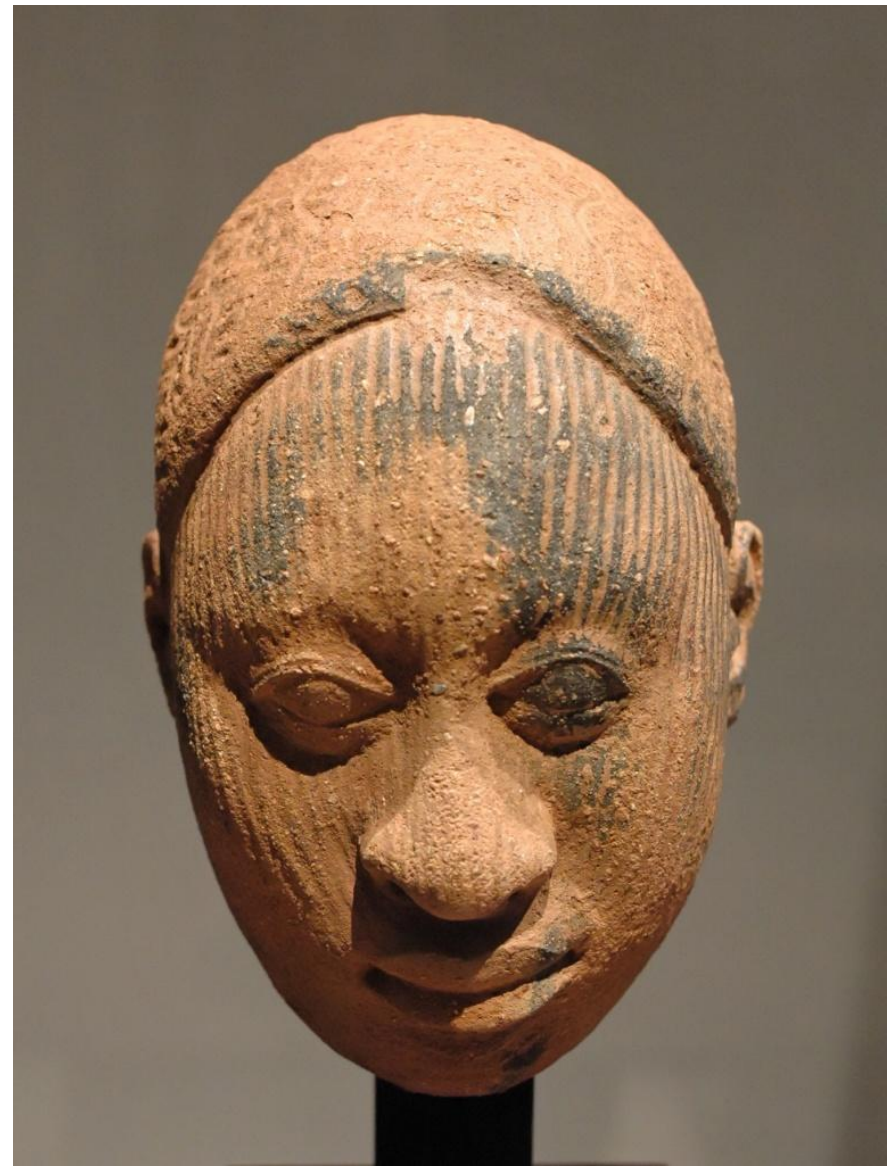

Figura 03. Peça em terracota, produzida durante o reino Ifê ou Ilé-Ifê yorubá, na Nigéria. Fonte: http://pt.wikipedia.org/wiki/L\%C3\%ADngua_iorub\%C3\%A1. Acesso em 22/02/2013.

Já no caso dos Abelam, envolvidos pelo território da Nova Guiné, o uso das cores (caso principal do vermelho, amarelo, branco e negro), dispostas em figuras ovais, também seria outro indicativo da conexão entre arte e vida, portanto necessário de compreensões em um plano semiótico. Pensadas como símbolos de poder, as tintas na cultura Abelam desempenhariam o papel de substâncias poderosas de elementos relacionados com os ritos, de maneira a serem inseridas em formulações ovais (Figura 04), representações da criatividade feminina. Sua atenção para o universo biológico feminino se dariam principalmente pelo fato de as mulheres terem sido as primeiras interlocutoras e amantes dos seres sobrenaturais. 


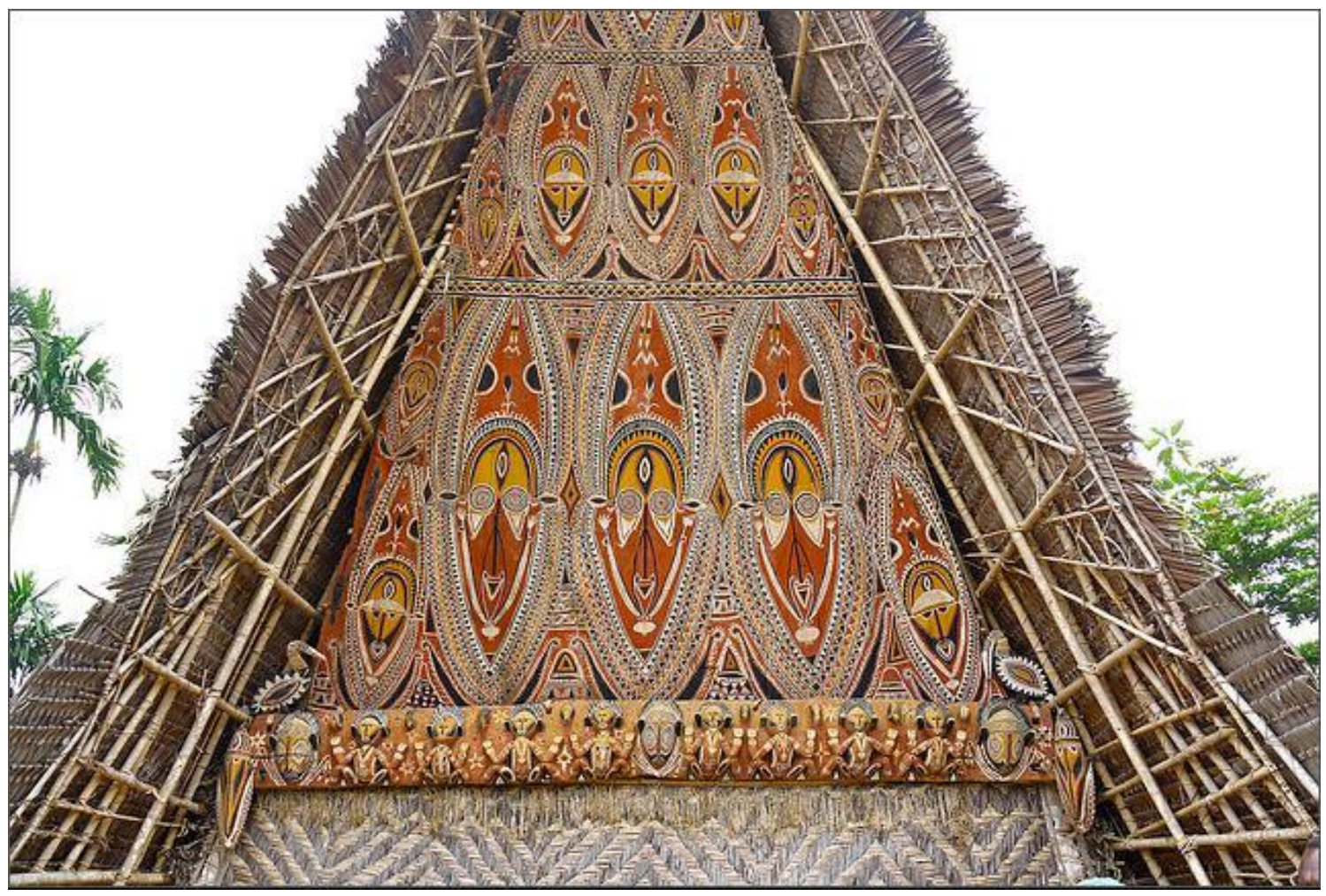

Figura 04. Fachada de contrução Abelam com arte em pintura plana. Fonte: http://www.flickriver.com/photos/rietje/sets/72157622994179702/. Acesso em 10/03/2014.

De qualquer forma, longe de promulgarem a celebração de estruturas sociais ou doutrinas úteis, os processos artísticos, sob a ótica de Geertz, foram aproximados da necessidade de uma história natural de seus indicadores e símbolos, bem como de uma etnografia dos seus veículos transmissores de significados, com o intuito, para além de conjugar semânticas abstratas, requerer alternativas de entender os fatores que os tornam importantes. Consciente de toda uma esteira histórica de transformações, de trocas entre contextos locais, nacionais e globais, a premissa de um olhar interpretativista para as artes seria o de combinar cultura e imagem. Aderente da ideia de vínculos simbólicos e afetivos ${ }^{13}$ coletivos, transversalizados pelo caráter individual disruptor e às vezes parceiro na disrupção, um interpretativismo neste universo seria determinante para refletir uma proposta conceitual sensível e passível de todo um jogo de poderes e uma variedade de formas de dialogar com o mundo social (Geertz, 2008a).

Ainda que uma antropologia estética implique em uma série de fatores difíceis de ser conjugados, visto o fato de que, na prática, o seu campo de ação está em

\footnotetext{
${ }^{13}$ Essa expressão se refere à dimensão na qual sujeito e experiência se ligam ao mundo e o vivem, codificam e criam laços de historicidade (Silveira \& Lima Filho, 2005).
}

Iluminuras, Porto Alegre, v. 15, n. 35, p. 11-43, jan./jul. 2014 
efervescente crescimento, não podemos abrir mão da inclusão de variadas perspectivas para um melhor multifacetamento dos contextos em análise. Mesmo alocados em uma zona tremendamente fragmentária e transdisciplinar, algo coerente quando se pensa que as artes são uma reunião de fragmentos narrativos visuais e contextuais, os processos artísticos, sob o olhar da antropologia, buscam evitar o terreno insalubre do virtuosismo de análise verbal sem nenhum sentido (Geertz, 2011), de maneira a privilegiar uma colcha ampla de significados e significantes. Ou então, pelo menos à luz das problemáticas hermenêuticas, colocar à disposição uma fagulha importante da realidade desses fenômenos sociais e geralmente inconclusos de fulgurarem no intuito antropológico de captar a realidade.

\section{Algumas Considerações}

O universo que abarca as noções e campos convergentes de arte e cultura, arte e antropologia, mesmo recente para os campos das ciências sociais modernas, observada sua concretização maior na década de 1950 com as incursões de Franz Boas, já se comporta polifônico e geralmente divergente.

Se durante as primeiras reflexões antropológicas sobre regimes visuais muitas artes ganharam a alcunha de "primitivas", entendimento este que contribuiu para acentuar uma ausência de conhecimento a respeito de suas reais diferenças (Geertz, 2008a), aos poucos estas relações estáveis e homogêneas cederam lugar para um caráter disruptor, coerente com a noção de cultura no entremeio da interlocução, negociação e transformação.

A filosofia, pelo que pôde ser conversado pela presente cartografia, mostrou um papel muito forte para auxiliar noções menos estáveis e destituídas dos cânones ocidentais, urbanos e europeus. Seja pela estreita relação com os protocolos alemães, via Octave Hamelin, seja pela virada hermenêutica a partir de Clifford Geertz, sua presença inspirou um campo passível de se tornar multidisciplinar e complexo, ainda mais quando trazemos para nosso mundo contemporâneo, onde temporalidades se estimulam e se reconstroem ao lado de conflitos geo-históricos, políticos e econômicos interdependentes.

Longe da ideia de um colecionismo de materiais heterogêneos, o presente artigo buscou evidenciar como o pensamento é capaz de (re)criar redes de entendimentos sociais que estão em simbiose e desterritorialização. É neste pontual percurso, por 
conseguinte, que são confrontados ruídos e reinscrições de pensamentos muitas vezes não aproximáveis, mas eficazes para visualizar a transformação de alguns dos meios iniciais de acesso para o nosso estado atual de diálogos e dissonâncias empíricas e teóricas.

No atual contexto de eternas quase respostas (meio perguntas), prevalece uma vontade de uma etnografia dos veículos que transmitem significados. Ainda que o interpretativismo de Clifford Geertz tenha sido alvo de controvérsias para uma ampla discussão da antropologia pós-moderna, bem como para o olhar do antigo outro, já transformado em intérprete de si mesmo (vide as cadeias de análises decoloniais e póscoloniais), resiste sua constatação de localizar no significado, dentro do contexto artístico, as diferentes origens de poder creditados a regimes de visualidades, não mais concebidos como autônomos nem inatos.

\section{Referências}

ALMEIDA, K. M. P. Por uma Semântica Profunda: Arte, Cultura e História no Pensamento de Franz Boas. Mana, Rio de Janeiro, n. 02, v. 04, 1998, p. 07-34.

BAKHTIN, M. Estética da Criação Verbal. São Paulo: Martins Fontes, 2003.

BAUDELAIRE, C. Sobre a Modernidade. São Paulo: Paz e Terra, 1996.

BENEDICT, R. Padrões de Cultura. São Paulo: Livros do Brasil, 1983.

O Crisântemo e a Espada. São Paulo: Perspectiva, 2002.

BOAS, F. Primitive Culture. New York, USA: Dover Publications, 1955.

As Limitações do Método Comparativo da Antropologia. In: CASTRO, C. (Org.).

Franz Boas: Antropologia Social. Rio de Janeiro: Jorge Zahar, 2010.

CAILLÉ, A. Nem Holismo nem Individualismo Metodológicos: Marcel Mauss e o Paradigma da Dádiva. Revista Brasileira de Ciências Sociais, São Paulo, n. 38, v. 13, 1998: 05-38.

CAMPOS, R. O; ZOETTL, P. A; CARVAlHO, M. R. G. Arte e Antropologia? Para Uma Espécie de Introdução. Cadernos de Arte e Antropologia, Salvador, v. 01, n. 01, 2012: 05-08.

CARDOSO DE OLIVEIRA, R. As "Categorias do Entendimento" na Antropologia. Anuário Antropológico 81. Rio de Janeiro: Tempo Brasileiro, 1983. 
O que é isso que Chamamos de Antropologia Brasileira?

Anuário Antropológico 85. Rio de Janeiro: Tempo Brasileiro, 1986.

A Categoria de (Des)Ordem e a Pós-Modernidade da Antropologia. Anuário Antropológico 86. Brasília: Tempo Brasileiro, 1988.

. Tempo e Tradição: Interpretando a Antropologia. In:

CARDOSO DE OlIVEIRA, R. Sobre o Pensamento Antropológico. Rio de Janeiro: Tempo Brasileiro, 2003.

CASTRO, C. Apresentação. In: CASTRO, C. (Org.). Franz Boas: Antropologia Social. Rio de Janeiro: Jorge Zahar, 2010.

CAUQUELIN, A. Teorias da Arte. São Paulo: Martins Fontes, 2005.

CLIFFORD, J. On Collecting Art and Culture. In: CLIFFORD, J. The Predicament of Culture: Twentieth-Century Ethnography, Literature and Art. Cambridge/ Massachussets/ London: Harvard University Press, 1988: 215-251.

COOTE, J; SHElton, A. Introduction. In: COOTE, J; SHELTON, A. (Org.). Anthropology, Art and Aesthetics. New York: Oxford University Press, 1992: 01-14.

CUCHE, D. A Noção de Cultura nas Ciências Sociais. Bauru, São Paulo: EDUSC, 2002.

DA MATTA, R. Repensando E. R. Leach. In: DA MATTA, R (Org.). Edmund Leach: Antropologia. São Paulo: Ática, 1983.

DURKHEIM, E. Les Formes Élémentaires de La Vie Religieuse: Le Système Totémique in Australie. Paris: Presses Universitaires de France, 1968.

EVANS-PRITCHARD, E. E. Antropologia Social: Primícias do Desenvolvimento Teórico. São Paulo: Edições 70, 1978.

FELDMAN BIANCO, B; MOREIRA LEITE, M. Desafios da Imagem: Fotografia, Iconografia e Vídeo nas Ciências Sociais. Campinas: Papirus, 1998.

FIRTH, R. Art and Anthropology. In: COOTE, J; SHELTON, A. (Org.). Anthropology, Art and Aesthetics. New York: Oxford University Press, 1992: 15-39.

GADAMER, H. G. Verdade e Método: Traços Fundamentais de uma Hermenêutica Filosófica. Petrópolis: Vozes, 1997.

GEERTZ, C. O Selvagem Cerebral: Sobre a Obra de Claude Lévi-Strauss. Cadernos de Campo, São Paulo, n. 12, 2004: 119-132.

A Arte Como um Sistema Cultural. In: GEERTZ, C. O Saber Local: Novos Ensaios em Antropologia Interpretativa. Petrópolis: Vozes, 2008a.

Iluminuras, Porto Alegre, v. 15, n. 35, p. 11-43, jan./jul. 2014 
Como Pensamos Hoje: A Caminho de uma Etnografia do Pensamento Moderno.

In: GEERTZ, C. O Saber Local: Novos Ensaios em Antropologia Interpretativa. Petrópolis: Vozes, 2008b.

Nós/ Não Nós: As Viagens de Benedict. In: GEERTZ, C. Obras e Vidas: O Antropólogo como Autor. Rio de Janeiro: UFRJ, 2009.

. A Interpretação das Culturas. Rio de Janeiro: Editora Zahar, 2011.

GELL, A. The Technology of Enchantment and the Enchantment of Technology. In: COOTE, J; SHELtON, A. (Org.). Anthropology, Art and Aesthetics. New York: Oxford University Press, 1992: 40-66.

GLISSANT, É. Introdução a uma Poética da Diversidade. Juiz de Fora: UFJF, 2005.

GUIA PRÁTICO DE ANTROPOLOGIA. São Paulo: Cultrix, 1971.

HISSA, C. E. V. Entrenotas: Compreensões de Pesquisa. Belo Horizonte: UFMG, 2013.

HOFBAUER, A. Entre Olhares Antropológicos e Perspectivas dos Estudos Culturais e PósColoniais: Consensos e Dissensos no Trato das Diferenças. Antropolítica, Niterói, n. 27, v. 02, 2009: 99-130.

KANT, I. Crítica da Faculdade do Juízo. Rio de Janeiro: Forense Universitária, 2012.

LAGROU, E. M. Antropologia e Arte: Uma Relação de Amor e Ódio. Ilha Revista de Antropologia, Florianópolis, v. 5, 2003: 93-113.

LE GOFF, J. Memória. In: LE GOFF, J. História e Memória. Campinas: UNICAMP, 2010, pp. 419-476.

LÉVI-STRAUSS, C. A Obra de Marcel Mauss. In: MAUSS, M. Sociologia e Antropologia. São Paulo: Edusp, 1974:. 01-36.

As Estruturas Elementares do Parentesco. Petrópolis: Vozes, 1982. Antropologia Estrutural. Rio de Janeiro: Tempo Brasileiro, 1985. .O Pensamento Selvagem. Campinas: Papirus, 2008.

LÉVI-STRAUSS, C.; CHARBONNIER, G. Arte, Linguagem, Etnologia: Entrevistas com Claude Lévi-Strauss. Campinas: Papirus, 1989.

LOPES PONTES, A. C. Lévi-Strauss e a Arte Moderna: o Impressionismo e o Cubismo. Proa: Revista de Antropologia e Arte, São Paulo, n. 02, v. 01, 2010. Disponível em http://www.ifch.unicamp.br/proa/ArtigosII/amandapontes.html. Acesso em 07/11/2012.

Iluminuras, Porto Alegre, v. 15, n. 35, p. 11-43, jan./jul. 2014 
LOTIERZO, T. Significação e Emoção Estética: Lévi-Strauss e um Olhar Antropológico sobre a Arte. Cadernos de Arte e Antropologia, n. ${ }^{\circ}$ 02, 2013: 109-127.

MAUSS, M. Manual de Etnografia. Lisboa: Pórtico, 1972.

MELATTI, C. Introdução. In: MELATTI, C. (Org.). Radcliffe-Brown. São Paulo: Ática, 1978.

MORGAN, L. H. A Sociedade Antiga. In: CASTRO, C (Org.). Evolucionismo Cultural: Textos de Morgan, Tylor e Fraser. Rio de Janeiro: Jorge Zahar, 2005.

NUNES, B. Introdução à filosofia da arte. São Paulo: Ática, 1991.

PASSETTI, D. V. Lé-vi-Strauss, Antropologia e Arte: Minúsculo-Incomensurável. São Paulo: Edusp/Educ, 2008.

PELLEGRINO, S. P. Antropologia e Visualidade no Contexto Indígena. Cadernos de Campo, São Paulo, n. ${ }^{\circ}$ 16, v. 16, 2007.

RADCLIFFE-BROWN, A. R. O Método Comparativo em Antropologia Social. In: ZALUAR, A. (Org.). Desvendando Máscaras Sociais. Rio de Janeiro: Francisco Alves, 1980.

SAID, E. Orientalismo: O Oriente como Invenção do Ocidente. São Paulo: Companhia das Letras, 2007.

SCHWARCZ, L. K. M. Uma História de "Diferenças e Desigualdades": as Doutrinas Raciais do Século XIX. In: SCHWARCZ, L. M. O Espetáculo das Raças: Cientistas, Instituições e Questão Racial no Brasil. São Paulo: Companhia das Letras, 1993.

SILVEIRA, F. L. A.; LIMA FILHO, M. F. Por uma Antropologia do Objeto Documental: Entre a "Alma nas Coisas" e a Coisificação do Objeto. Horizontes Antropológicos, Porto Alegre, n. $23,2005$.

SOUZA, C. D.; GOLDSTEIN, I. Lévi-Strauss, antropologia e arte. Minúsculo-incomensurável. Revista de Antropologia. Revista de Antropologia, São Paulo, v. 51, n. 1, 2008: 313-320.

STOCKING, G. W. Race, Culture and Evolution: Essays in the History of Anthropology. Chicago: University of Chicago Press, 1968.

STOCKING JR., G. W. Os Pressupostos Básicos da Antropologia de Boas. In. STOCKING JR., G. W. (Org.). A Formação da Antropologia Americana 1883-1911: Antologia/ Franz Boas. Rio de Janeiro: Contraponto: UFRJ, 2004.

THOMPSON, A. Recompondo a Memória: Questões sobre a Relação entre a História Oral e as Memórias. Projeto História 15, São Paulo, n. 15, 1997: 51-71.

TYLOR, E. B. A Ciência da Cultura. In: CASTRO, C (Org.). Evolucionismo Cultural: Textos de Morgan, Tylor e Fraser. Rio de Janeiro: Jorge Zahar, 2005.

Iluminuras, Porto Alegre, v. 15, n. 35, p. 11-43, jan./jul. 2014 
VIVEIROS DE CASTRO, E.; GOLDMAN, M. Introduction to Post-'Social Anthropology: Networks, Multiplicities, and Simmetrizations. Hau: Journal of Ethnographic Theory, v. 2, 2012: 421-433. 